\title{
Analisis Kenyamanan Termal Ruang Terbuka Publik Hunian Vertikal. Studi Kasus: Apartemen Kebagusan City Jakarta
}

\author{
Akbar Rizky Pratama \\ Program Magister Kajian Pengembangan Perkotaan, SKSG, Universitas Indonesia \\ e-mail: rizkypratama.akbar@gmail.com
}

\begin{abstract}
Abstrak - Isu pemanasan global merupakan ancaman yang nyata dan sangat terasa di kawasan perkotaan, terutama di kawasan hunian. Temperatur lingkungan kediaman yang melebihi tinggi suhu bangunan lainnya, tingkat kenyamanan merupakan salah satu dampaknya. Hal ini tidak terlepas dari fenomena 'Pulau Panas Perkotaan', akibat lebih tingginya temperatur lingkungan dibanding dengan tingkat kenyamanan penghuni. Tujuan penelitian adalah untuk mengukur seberapa puas dan nyaman penghuni hunian vertikal di Apartemen Kebagusan City Jakarta. Peneliti menerapkan metode dalam penelititian ini dengan cara membandingkan persepsi penghuni terhadap kenyamanan termal, dengan simulasi penghitungan kenyamanan termal. Hasil penelitian ini memperlihatkan, dengan rata-rata temperatur udara berada pada kisaran $33^{\circ} \mathrm{C}$ pada siang hari, ditambah dengan pola aktivitas serta pola sirkulasi angin yang ada, penghuni masih merasakan kondisi sejuk meskipun dalam simulasi menunjukkan nilai hangat. Apartemen Kebagusan City menggunakan bebeberapa rekayasa bangunan seperti konfigurasi gedung, bahan dan warna, serta berbagai rekayasa lainnya untuk mengatur tingkat kenyamanan termal di kawasan permukiman.
\end{abstract}

Kata Kunci-Hunian Vertikal, Kenyamanan Termal, Pemanasan Global, Pulau Panas Perkotaan, Ruang Terbuka Publik.

\section{PENDAHULUAN}

$\mathrm{K}$ awasan permukiman di perkotaan menghadapi isu yang sangat nyata dan global mengenai perubahan iklim. Temperatur lingkungan tinggal yang berada di atas ratarata tingkat kenyamanan merupakan salah satu dampaknya. Hal ini tidak terlepas dari fenomena 'Pulau Panas Perkotaan' yang terlihat dari tingginya suhu suatu daerah melebihi daerah lainnya [1] [2]. Fenomena UHI = urban heat island atau biasa disebut pulau panas perkotaan adalah fenomena yang terjadi akibat adanya perbedaan suhu perkotaan yang mencolok dibandingkan dengan wilayah sekitarnya. UHI merupakan salah satu indikator untuk evaluasi kondisi lingkungan (kenyamanan) suatu perkotaan[3]Suhu disini bisa meliputi suhu udara ataupun suhu permukaan lahan[4]. Umumnya fenomena ini terjadi di perkotaan dengan bangunan atau gedung-gedung dan jaringan jalan yang rapat atau daerah industri yang padat yang dikelilingi pinggiran kota atau lahan bervegetasi[5][6]. Pembangunan secara vertikal serta kurangnya ruang terbuka hijau dapat memperburuk kondisi kenaikan suhu di wilayah perkotaan.

Akibat dari lebih tingginya temperatur lingkungan dibanding dengan tingkat kenyamanan penghuni, frekuensi pemakaian teknologi guna menurunkan temperatur menjadi lebih tinggi tinggi pula. Salah satunya adalah penggunaan pendingin ruangan atau AC. Penggunaan AC bukanlah tanpa efek samping. Perangkat ini menghasilkan gas buang yang dapat memperparah kenaikan temperatur. Selain AC, aktivitasaktivitas perkotaan lainnya seperti kendaraan bermotor, aktivitas industri, dan lain sebagainya, akan menambah hangat suhu udara di wilayah perkotaan. Kenaikan suhu permukaan ini berakibat pada peningkatan fluks bahang terasa (sensible heat $f l u x)$ dan suhu udara. Kondisi ini akan berpotensi menimbulkan fenomena pulau panas perkotaan[7].

Siklus problematika iklim dan kenyamanan termal perkotaan merupakan pembahasan yang sangat erat terkait dengan agenda adaptasi dan mitigasi perubahan iklim[8]. Pemerintah dengan perannya dalam merangkul semua pihak untuk terlibat dalam agenda ini telah menstrukturkan kebijakankebijakan terkait pembangunan berkelanjutan. Untuk memahami permasalahan ini, maka langkah awal yang perlu diketahui adalah bagaimana tingkat kenyamanan termal di kawasan yang memiliki tingkat konsentrasi penduduk yang padat di wilayah perkotaan. Hal yang paling merepresentasikan kondisi tersebut adalah perumahan-perumahan vertikal. Selain tingkat kepadatan penduduk yang tinggi, hunian vertikal pun memiliki fitur-fitur yang mempengaruhi variabel penelitian kenyamanan termal, seperti struktur bangunan, konfigurasi bangunan, vertical obstruction, dan lain sebagainya.

Objek pengukuran tingkat kenyamanan termal dalam penelitian ini adalah Apartemen Kebagusan City, yang terletak di Kota Jakarta Selatan, tepatnya di Jl. Baung Raya Tanjung Barat, RT.2/RW.3, Kebagusan, Pasar Minggu. Apartemen ini terletak di tengah wilayah permukiman di selatan Jakarta, dan berbatasan dengan Depok.

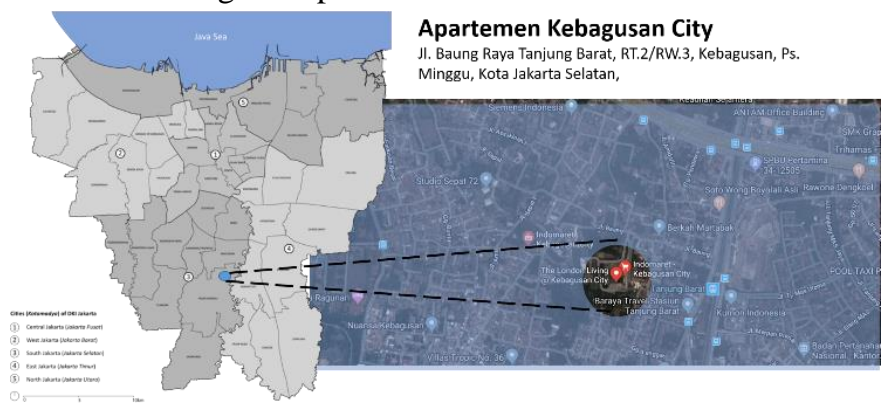

Gambar 1. Peta Lokasi Apartemen Kebagusan City

Apartemen Kebagusan City sendiri merupakan komplek yang terdiri dari 3 tower, yang masing masing memiliki bentuk seperti huruf "L" (L Shape). Di antara gedung apartemen, terdapat dua ruang terbuka yang digunakan sebagai ruang publik. Ruang terbuka pertama berupa taman bermain anak 
yang bisa dimasuki oleh siapapun, dan ruang terbuka lainnya berupa kolam renang yang akses masuknya terbatas. Di sekililing apartemen merupakan ruang terbuka juga yang difungsikan sebagai tempat parkir.

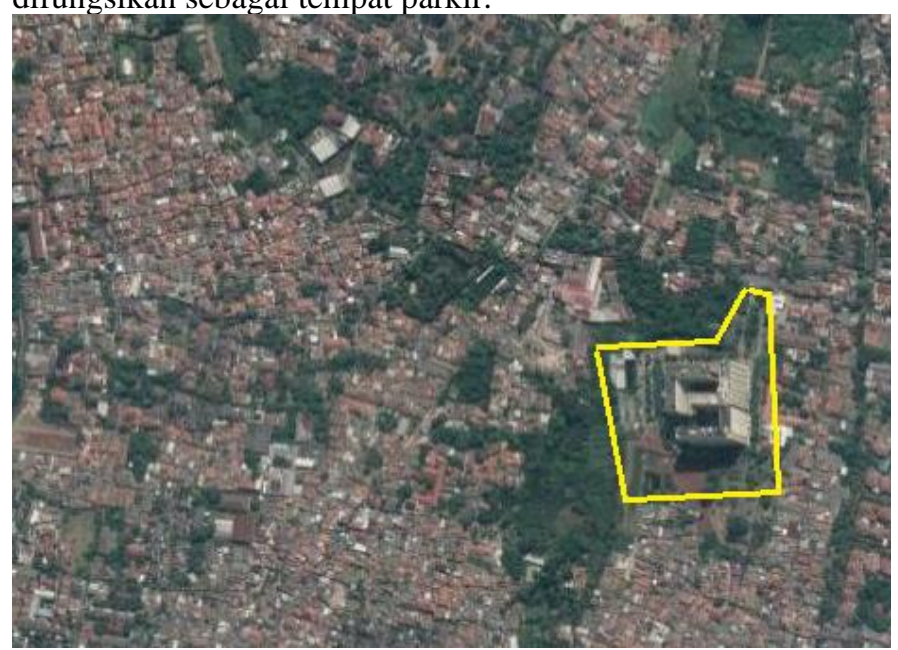

Gambar 2. Citra Satelit Apartemen Kebagusan City

Tujuan penelitian ini adalah untuk mengukur seberapa puas dan nyaman penghuni hunian vertikal (apartemen). Dengan mengetahui tingkat kenyamanan termal secara mikro, maka dapat diuraikan kondisi iklim yang disesuiakan dengan konteks di lingkungan tersebut. Dari kondisi itu pula dapat ditarik benang merah antara kondisi iklim mikro eksisting dengan usaha implementasi kebijakan agenda adaptasi dan mitigasi yang perannya diampu oleh pemerintah dalam rangka usaha membangun lingkungan yang berkelanjutan.

\section{METODE PENELITIAN}

Kenyamanan termal melibatkan kondisi psikologis dan fisiologis manusia. Hal-hal yang kualitatif akan memberikan suatu penilaian yang subyektif [9]. Oleh karena itu, penting untuk membandingkan tingkat kenyamanan termal menurut persepsi penghuni dengan kondisi riil dari pengukuran yang bersifat kuantitatif.

Metode yang diterapkan dalam penelitian ini adalah dengan membandingkan persepsi penghuni terhadap kenyamanan termal, dengan simulasi penghitungan kenyamanan termal menggunakan comfort calculator.

Metode pengumpulan data pada penelitian ini dengan dua cara. Untuk data simulasi, digunakan aplikasi Wind Compass untuk melihat kondisi iklim mikro berupa temperatur udara, kelembapan udara, serta kecepatan angin. Sedangkan persepsi penghuni diketahui menggunakan metode kuesioner.

Keseluruhan data diambil pada hari Minggu tanggal 16 Februari 2020. Untuk menentukan rentang waktu penelitian, dilakukan kajian profil iklim wilayah DKI Jakarta Selatan melalui prakiraan iklim BMKG. Dalam kajian tersebut, diketahui bahwa temperatur rataan maksimum diprediksi sebesar $33,6^{\circ} \mathrm{C}$ pada siang hari, sedangkan temperatur rataan minimum sebesar $22,0^{\circ} \mathrm{C}$ pada malam hari. Sedangkan kelembapan minimun diprediksi sebesar $87 \%$ pada malam hari, dan minimun sebesar $64 \%$ pada siang hari. Oleh karena itu, sampel waktu yang diambil dalam penelitian ini, adalah siang hingga malam hari yaitu sekitar jam 14.00 WIB sampai 20.00
WIB. Pengambilan data baik berupa persepsi konsumen maupun pengukuran riil dilakukan pada hari yang sama.

\section{A. Simulasi}

Simulasi penghitungan kenyamanan termal dilakukan menggunakan comfort calculator dengan memasukan nilai variabel untuk temperatur udara, temperatur radian, kelembapan udara, serta kecepatan angin. Variabel-variabel tersebut diukur menggunakan aplikasi agar mendapatkan nilai yang pasti. Setelah itu, ditambahkan variabel aktivitas penghuni dan pakaian.Untuk mendapatkan data ini, maka dilakukan pengamatan langsung. Aktivitas penghuni diukur dari yang paling rendah yaitu tidak melakukan apa-apa, hingga yang tertinggi berupa kegiatan-kegiatan berat. Sedangkan untuk pakaian, diukur dari nilai terendah yaitu tidak menggunakan pakaian atau menggunakan pakaian tipis, hingga yang tertinggi berupa penggunaan pakaian tebal.

Nilai dari keseluruhan variabel tersebut kemudian dimasukan sehingga didapatkan nilai kenyamanan termal di wilayah terebut berupa spektrum yang menunjukkan nilai terendah -3 , hingga yang tertinggi +3 . Nilai -3 diterjemahkan dengan kondisi temperatur yang sangat dingin, dan +3 menunjukkan temperatur yang sangat panas. Kondisi ideal diasumsikan berada pada nilai sekitaran 0 (nol) yang diterjemahkan dengan kondisi temperatur yang netral.

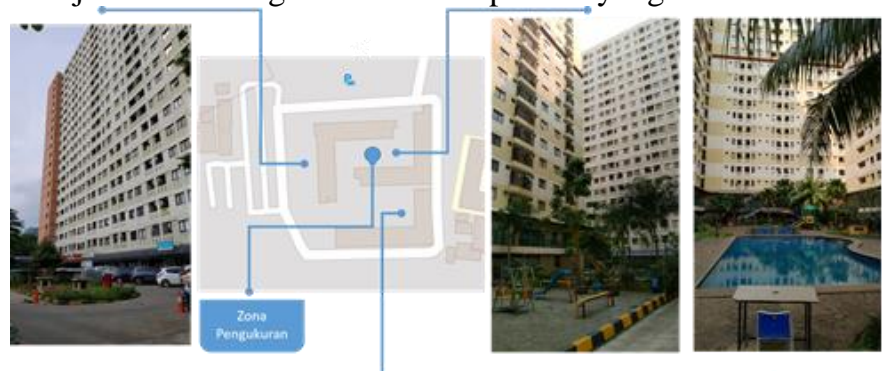

Gambar 3. Zona Pengukuran di Ruang Terbuka Apartemen Kebagusan City

Pengukuran dilakukan di ruang terbuka yang dapat diakses semua orang, yaitu taman bermain anak-anak, bagian luar kolam renang, dan juga tempat parkir. Pengukuran yang dilakukan di titik-titik ini adalah temperatur udara, kelembapan udara, serta kecepatan dan arah angin. Sedangkan pengamatan aktivitas serta pakaian penghuni dilakukan dengan cara berkeliling di komplek apartemen.

\section{B. Persepsi Penghuni}

Tingkat kenyamanan termal lingkungan tempat tinggal juga dicari dengan menanyakan langsung persepsi para penghuninya. Target responden dalam penelitian ini adalah penghuni unit apartemen, baik itu dalam unit hunian tinggal, maupun unit kantor/tempat usaha.Metode yang digunakan adalah dengan penyebaran kuesioner dengan jumlah responden sebanyak 50 orang. Agar hasil kuesioner dapat dibandingkan dengan hasil simulasi, maka output yang dirancang juga disamakan dengan output hasil dari simulasi berupa spektrum kenyamanan. Dalam simulasi, spektrum terbagi ke dalam 5 kriteria yaitu, dingin, sejuk, netral, hangat, dan panas. Untuk kuesioner, spektrum tersebut dimodifikasi menjadi dingin, agak dingin, sejuk, hangat, dan panas guna mempermudah responden memahami pertanyaan. Masing-masing indikator kenyamanan 
kemudian diberikan bobot. Indikator dingin diberikan bobot nilai (1), agak dingin (2), sejuk (3), hangat (4), dan panas (5). Bobot ini digunakan agar dapat diketahui rataan kenyaman penghuni dalam bentuk nilai yang terukur.

\section{HASIL DAN PEMBAHASAN}

\section{A. Hasil Simulasi}

Dari hasil pengukuran, diketahui temperatur udara di apartemen Kebagusan City mengalami penurunan berdasarkan waktu. Semakin malam, temperatur udara semakin dingin. Saat pengukuran dimulai pukul 14.00 WIB atau siang hari, temperatur sekitar menunjukkan angka $33^{\circ} \mathrm{C}$. Sedangkan untuk malam hari temperatur terendah yang terukur mendapati hasil $26^{\circ} \mathrm{C}$. Meskipun mengalami penurunan, namun temperatur terendah pada malam hari masih di atas angka $25^{\circ} \mathrm{C}$.

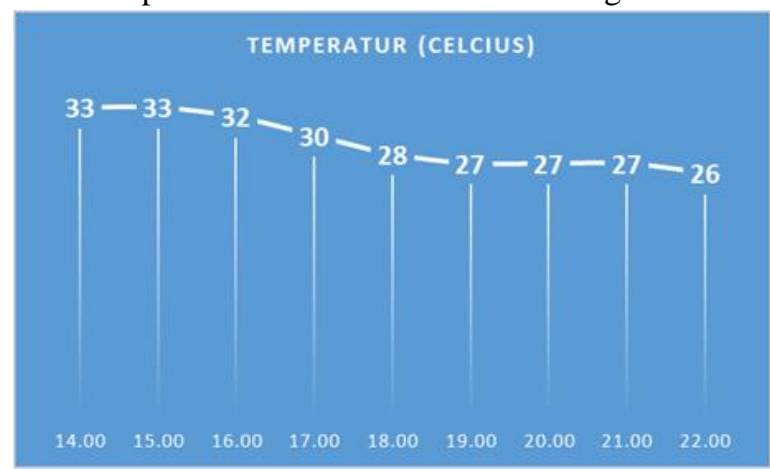

Gambar 4. Grafik Temperatur Udara di Apartemen Kebagusan City

Untuk kelembapan udara,dihitung mulai jam 14.00 WIB sampai jam 22.00 WIB. Hasilnya memperlihatkan grafik yang meningkat. Kelembapan udara terukur pada siang hari pukul 14.00 WIB adalah sebesar 50\%. Semakin malam, udara sekitar semakin lembap dengan kelembapan terukur pada pukul 22.00 adalah sebesar $81 \%$.

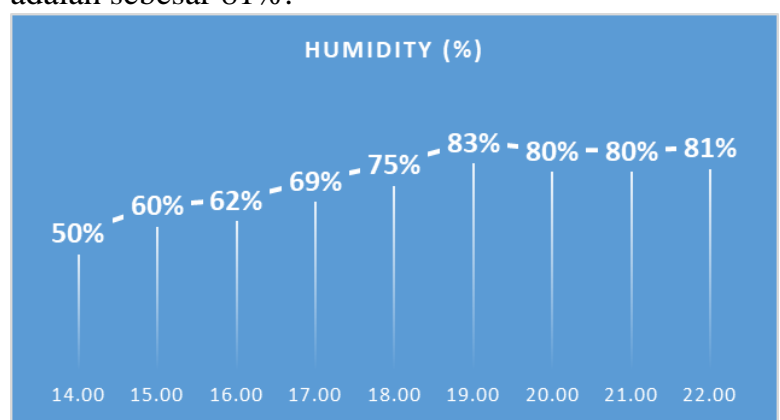

Gambar 5. Grafik Kelembapan Udara di Apartemen Kebagusan City

Kecepatan angin yang diukur di Apartemen Kebagusan City menunjukkan hasil yang bervariasi dari siang hari hingga malam hari. Pada siang hari, kecepatan angin yang terukur di jam 14.00 WIB adalah sebesar 4,2 meter/detik. Kecepatan tertinggi terukur saat sore sekitar jam 16.00 WIB sebesar 5,4 meter/detik. Setelah itu, kecepatan angin perlahan menurun hingga nilai terendah yang terukur pada pukul 19.00 WIB sebesar 2,1 meter/detik. Kecepatan angin kemudian relatif bervariasi dengan kecepatan tertinggi terukur pada pukul 20.00 WIB sebesar 3,5 meter/detik dan terendah pada pukul 22.00
WIB sebesar 2,2 meter/detik. Pada siang hari, angin bergulir dari arah barat daya mengarah ke timur laut berembus di Apartemen Kebagusan City. Sedangkan di malam hari arah angin berganti dari arah timur laut ke arah barat daya. Titik perubahan arah angin ini bersamaan dengan titik temperatur terendah yang terukur yaitu sekitar pukul 19.00 WIB. Saat angin sudah berputar arah, perlahan temperatur udara pun menunjukkan kenaikan angka pengukuran meski rata-ratanya di bawah angka temperatur pada siang hari.
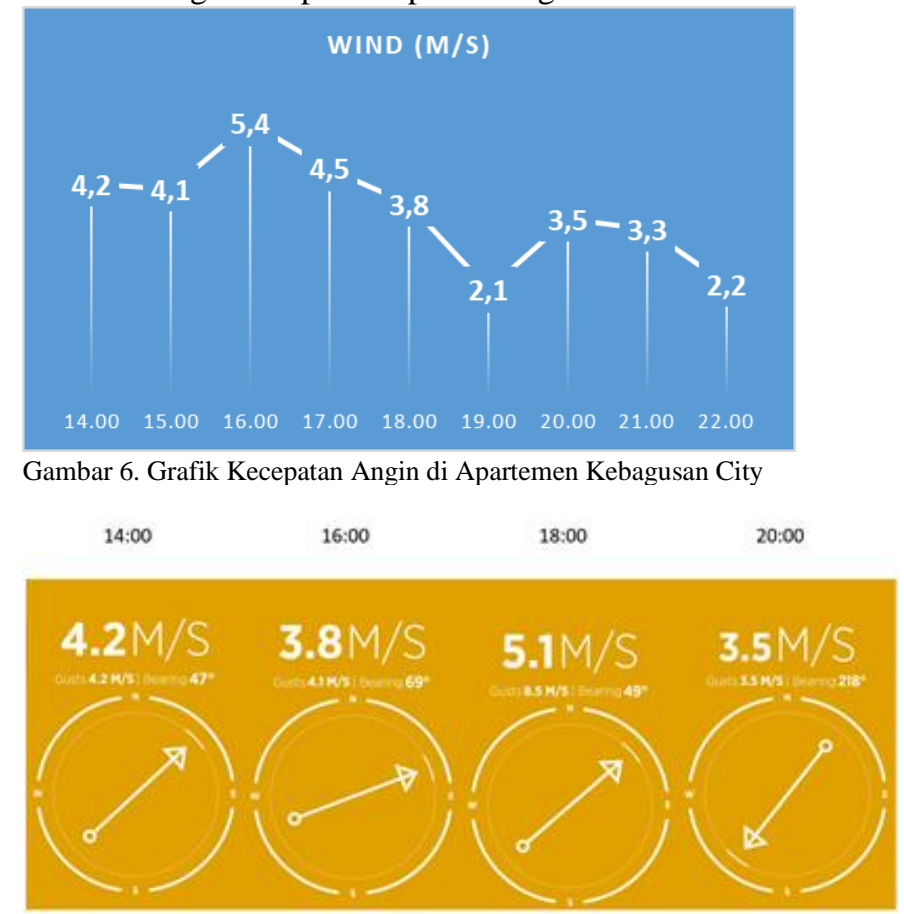

Gambar 7. Arah Angin di Apartemen Kebagusan City

Simulasi untuk kondisi di siang hari menunjukkan hasil kenyamanan yang diindikasikan dengan temperatur hangat mendekati panas dengan rerata nilai 1,5. Persentase ketidaknyamanan mencapai angka 50,9\%.

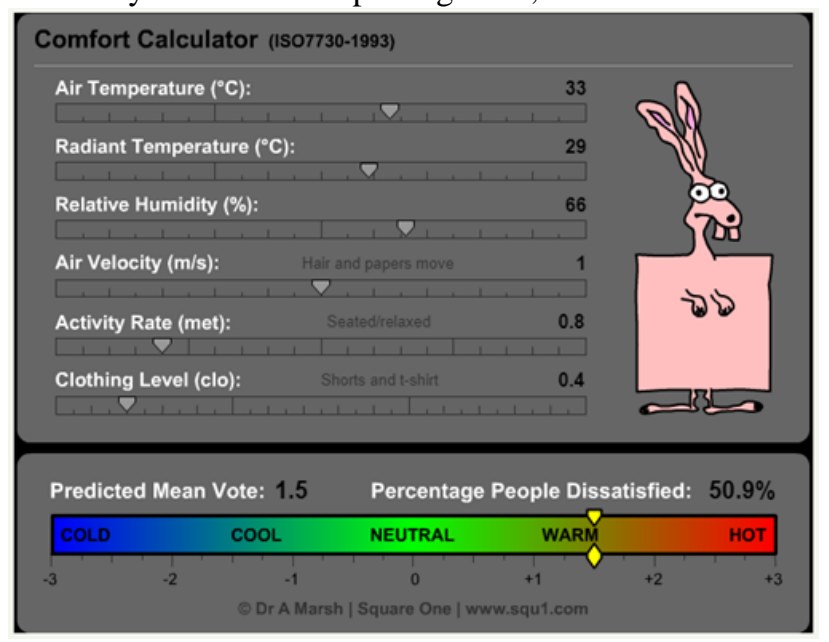

Gambar 8. Hasil Simulasi Pukul 14.00 WIB-15.59 WIB 


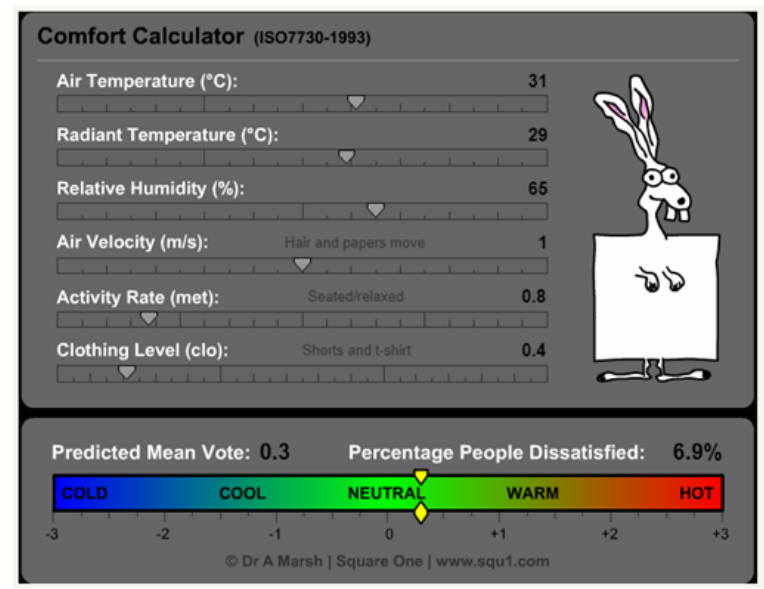

Gambar 9. Hasil Simulasi Pukul 16.00 WIB-17.59 WIB

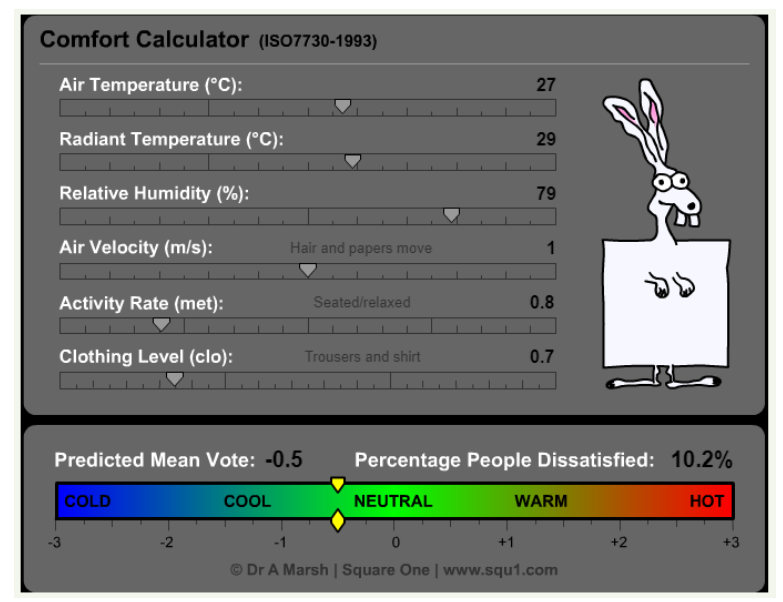

Gambar 10. Hasil Simulasi Pukul 18.00 WIB-19.59 WIB

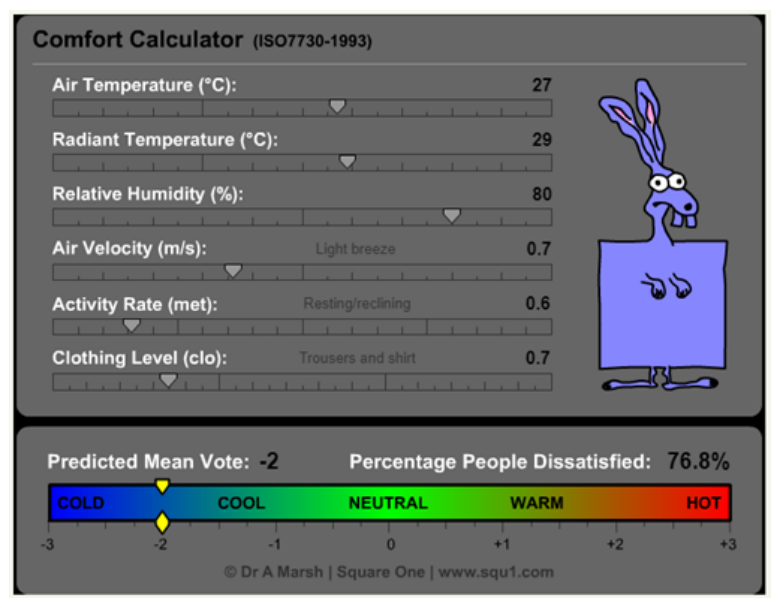

Gambar 11. Hasil Simulasi Pukul 20.00 WIB-21.59 WIB

Di sore hari, tepatnya ketika perhitungan dilakukan pada pukul 16.00 WIB-17.59 WIB, kenyamanan termal bergeser ke arah yang lebih netral dengan nilai 0,3. Pada jam tersebut persentase ketidakpuasan menurun drastis jadi hanya sebesar 6,9\%.Untuk pengukuran di antara pukul 18.00 WIB-19.59 WIB (senja menuju malam), spektrum kenyamanan semakin bergeser ke arah sejuk di bawah netral. Angka kenyamanan berada pada nilai $-0,5$. Persentase ketidaknyamanan pun menjadi meningkat lagi ke angka 10,2\%, meski masih dalam kategori nyaman.Sedangkan pengukuran di malam hari (pukul
20.00 WIB-21.59 WIB), menunjukkan pergeseran spektrum ke arah dingin. Angka kenyamanan berada di level -2. Persentase ketidaknyamanan pun menjadi tinggi yaitu 76,8\%. Lebih tinggi dibandingkan dengan kondisi di siang hari.

\section{B. Tingkat Persepsi Penghuni}

Tingkat kenyamanan termal yang didapatkan dari hasil kuesioner penghuni menunjukkan bahwa di siang hari, 60\% penghuni merasakan temperatur di kawasan tersebut sejuk, dan $40 \%$ sisanya berpendapat temperatur yang mereka rasakan adalah hangat. Nilai bobot rata-rata yang didapatkan di siang hari adalah sebesar 3,4, dengan nilai 3 sebagai patokan netral. Untuk di sore hari, penghuni yang merasakan bahwa temperatur di kawasan tersebut sejuk bertambah menjadi 85\%, dan sisanya menganggap temperatur di waktu tersebut adalah hangat. Bobot rata-rata kenyamanan di sore hari turun menjadi 3,2. Pada senja hari menuju malam, $40 \%$ penghuni merasakan kawasan tersebut memiliki temperatur yang agak dingin. Sedangkan $60 \%$ penghuni berpendapat temperatur pada waktu tersebut adalah sejuk. Bobot rata-rata yang dihasilkan pada waktu tersebut adalah 2,6, yang berarti di bawah netral menuju dingin. Sedangkan di malam hari. $25 \%$ penghuni merasakan bahwa temperatur di kawasan tersebut menjadi dingin. Sebanyak $45 \%$ penghuni merasakan agak dingin, dan $30 \%$ penghuni berpendapat temperatur kawasan tersebut masih dapat dikatakan sejuk. Bobot rata-rata yang diperoleh pada malam hari adalah sebesar 2,1.

\section{Perbandingan Hasil Simulasi dengan Tingkat Persepsi Penghuni}

Untuk siang hari, meskipun rata-rata temperatur udara berada pada kisaran $33^{\circ} \mathrm{C}$, dengan pola aktivitas penghuni serta nilai kecepatan angin, menunjukkan bahwa di kawasan tersebut penghuni merasa bahwa kondisi tersebut masih tergolong sejuk,meskipun simulasi menunjukkan nilai hangat. Tidak ada perbedaan dari sore menjelang malam hari, baik dari hasil simulasi maupun persepsi penghuni. Kawasan tersebut masih dalam kategori sejuk dengan segala nilai variabel iklim mikro yang sudah diukur. Sedangkan untuk malam hari, iklim di kawasan ini cenderung agak dingin, baik dilihat dari hasil simulasi, maupun dari persepsi para penghuninya.

Tabel 1.

Perbandingan hasil simulasi dengan persepsi penghuni

\begin{tabular}{lllll}
\multicolumn{5}{c}{ Perbandingan hasil simulasi dengan persepsi penghuni } \\
\hline \hline & $\mathbf{1 4 . 0 0 -}$ & $\mathbf{1 6 . 0 0 -}$ & $\mathbf{1 8 . 0 0 -}$ & $\mathbf{2 0 . 0 0 - 2 1 . 5 9}$ \\
& $\mathbf{1 5 . 5 9}$ & $\mathbf{1 7 . 5 9}$ & $\mathbf{1 9 . 5 9}$ & \\
\hline Simulasi & Hangat & Sejuk & Sejuk & Agak Dingin \\
\hline Persepsi & Sejuk $(3,4)$ & Sejuk $(3,2)$ & Sejuk $(2,6)$ & $\begin{array}{l}\text { Agak Dingin } \\
(2,1)\end{array}$ \\
& & & & \\
\hline \hline
\end{tabular}

\section{Fisik Bangunan}

Gedung bangunan Apartemen Kebagusan City, memiliki fitur elemen bata padat dan kaca. Bata padat memiliki nilai kalor pada temperatur $25^{\circ} \mathrm{C}$ sebesar 1,31 . Sementara elemen kaca memliki nilai 1,05. Material bata padat lebih sedikit menyerap kalor dibandingkan dengan semen dan batu. Efek panas sangat besar (46\%) di sebabkan oleh sinar ultra violet (6\%), cahaya tampak (48\%) dan sinar infra merah yang dipancarkan radiasi matahari. Peneliti menemukan bahwa penyumbang panas terbesar yang masuk ke dalam bangunan 
adalah radiasi matahari. Fraksi radiasi yang dipantulkan dari permukaan disebut albedo, memainkan peran utama dalam keseimbangan energi permukaan bumi, karena iamenentukan tingkat bagian yang diserap dari radiasi matahari [10]. Bangunan apartemen menggunakan warna dominan terang, dari spektrum putih menuju krem. Dalam spektrum albeldo, semakin gelap warna, akan semakin menyerap kalor. Facade bangunan yang berupa perbandingan luas kaca dan luas dinding bangunan keseluruhan (wall to wall ratio), begitu pula jenis dan tebal kaca yang digunakan dapat mempengaruhi besarnya radiasi matahari yang ditransmisikan melalui selubung bangunan [10].

\section{E. Konfigurasi Bangunan}

Setiap gedung memiliki tower yang menghadap sisi barattimur, serta sisi utara-selatan. Hal ini menyebabkan ada sisisisi yang pada suatu waktu akan lebih hangat dibandingkan dengan sisi lainnya.

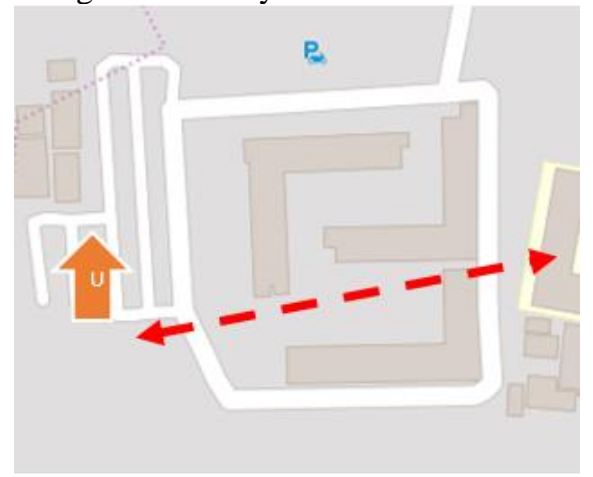

Gambar 12. Pengaruh Konfigurasi Bangunan Apartemen Kebagusan City terhadap Radiasi Matahari

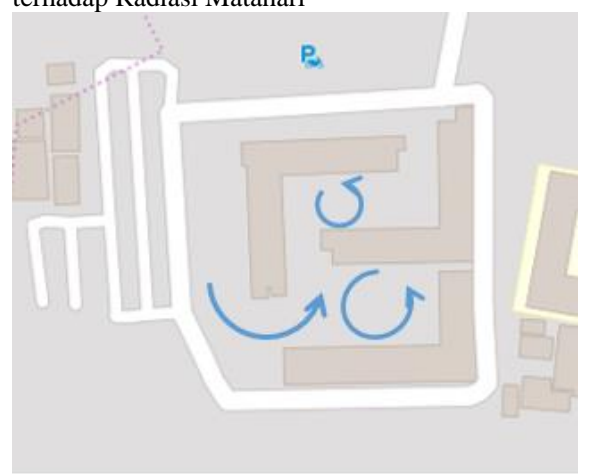

Gambar 13. Skenario Pergerakan Angin di Apartemen Kebagusan City Pada Siang Hari

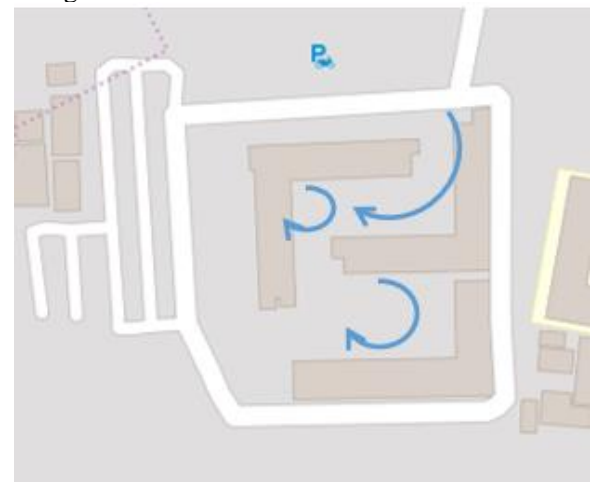

Gambar 14. Skenario Pergerakan Angin di Apartemen Kebagusan City Pada Malam Hari
Konfigurasi bangunan sendiri membentuk pola courtyard. Konfigurasi courtyardpada bukaan timur-barat, membuat radiasi matahari tidak terperangkap. Konfigurasi ini pun membuat kecepatan angin akan semakin kencang yang berimplikasi pada penurunan temperatur di wilayah setempat[11][12]. Kecepatan angin juga dipengaruhi oleh tingginya bangunan, sehingga angin yang masuk akan lebih banyak berputar di ruang terbuka yang memisahkan tower apartemen.

\section{F. Lingkungan Sekitar}

Apartemen Kebagusan City terletak di wilayah permukiman, tidak ada gedung-gedung tinggi di lingkungan sekitar menyebabkan kalor yang dihasilkan di wilayah tersebut tidak sebesar wilayah yang dikelilingi gedung-gedung tinggi. Hal ini pula yang membuat Apartemen Kebagusan City memiliki temperatur yang relatif sejuk.Di bagian barat daya lokasi tapak, terdapat ruang terbuka hijau yang cukup luas yang difungsikan sebagai area pemakaman serta hutan kota. Hal ini pula yang membuat wilayah sekitar menjadi sejuk karena daya serap kalor untuk hutan kayu hanya sebesar 0,08 hingga 0,15.

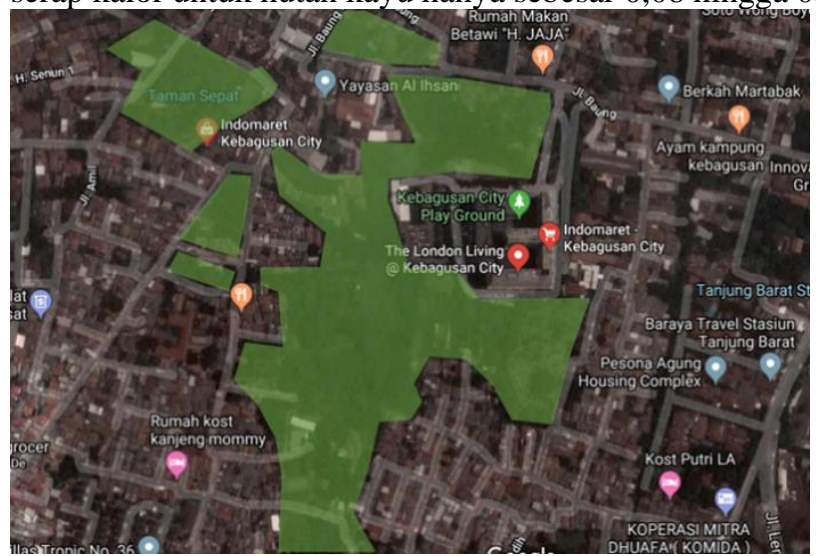

Gambar 15. Zona Hijau Eksisting di Sekitar Aparemen Kebagusan City

\section{G. Kebijakan Tata Ruang Terkait}

Berdasarkan peraturan zonasi yang diterbitkan oleh Dinas Tata Ruang dan Cipta Karya DKI Jakarta, wilayah Kebagusan City terletak dizona perencanaan Kecamatan Pasar Minggu. Di Zona ini guna lahan didominasi oleh perumahan KDB rendah serta zona jalur hijau. Wilayah tapak untuk apartemen Kebagusan City sendiri terletak di lingkungan perumahan vertikal KDB rendah, sub zona R-10 rumah vertikal KDB rendah. Hal ini membuktikan tidak ada kaitan antara kondisi keberadaan bangunan dan zonasi rencana yang sudah diatur pemerintah DKI Jakarta. Apartemen Kebagusan City dibangun di zona permukiman dan fungsi eksistingya pun tidak bertolak belakang dengan fungsi yang sudah ditetapkan.

Perencanaan pembangunan untuk upaya mitigasi dan adaptasi perubahan iklim sudah dilakukan oleh Pemerintah Indonesia. Salah satu tantangan yang harus dihadapi dalam pembangunan adalah perubahan iklim, hal ini tercantum dalam RPJPN 2005- 2025. Kemudian diinterpretasikan dalam RPJMN 2004 -2009, RPJMN 2010- 2014, RPJMN 2015-2019, dan strategi dalam pembangunan untuk mengantisipasi berubahnya iklim. Dijelaskan dalam dokumen Rencana Aksi Nasional Perubahan Iklim (RAN-PI) dan Indonesia Climate Change Sectoral Roadmap (ICCSR) tentang upaya antisipasi perubahan 
iklim secara spesifik. Rencana mitigasi ditujukan untuk mengurangi emisi gas rumah kaca pada bidang ekonomi yang utama, yaitu sektor energi, kehutanan, pertanian-perikanan, dan infrastruktur yang dilandaskan pada penetapan objek pengurangan per sektornya. Sedangkan rencana penyesuaian ditujukan untuk memajukan bentuk pembangunan yang kukuh terhadap pengaruh berubahnya iklim dan gangguan ketidaknormalan cuaca yang sedang terjadi, dan antisipasi pengaruh selanjutnya [13].

Pada arsip Rencana Aksi Nasional Adaptasi Perubahan Iklim [8], keberlangsungan kegiatan masyarakat khususnya sosial dan ekonomi dipengaruhi oleh pengaruh berubahnya iklim pada infrastruktur. Sebagian besar wilayah perkotaan dan juga wilayah khusus yang antara lain pulau-pulau kecil dan pesisir belum dibangun infrastruktur dengan pertimbangan perubahan iklim di masa akan datang. Sedangkan rancangan infrastruktur baru harus meninjau perkiraan pengaruh perubahan iklim yang akan terjadi. Maka, diperlukan panduan pelaksanaan dalam rencana aksi penyesuaian sub-bidang infrastruktur yang kuat dengan perubahan iklim. Sub-bidang infrastruktur membutuhkan pendekatan utama antara lain: [a] adaptasi terhadap bentuk, elemenen, racangan dan juga tempat infrastruktur yang kuat dengan perubahan iklim, [b] pembaharuan infrastruktur yang kelihatan lemah dalam menghadapi perubahan iklim, hal ini dapat berupa bentuk, manfaat dan tempatnya, dan [c] sarana kegiatan pengamatan dan penelitian tentang rancangan infrastruktur yang kuat dengan perubahan iklim.

Meninjau semangat akan penyesuaian berubahnya iklim, apartemen Kebagusan City sudah menerapkan strategi-strategi dalam membangun infrastruktur yang menjawab permasalahan perubahan iklim di kawasan Jakarta Selatan. Dengan isu pulau panas perkotaan dan temperatur yang semakin meningkat, apartemen Kebagusan City merancang sebuah konfigurasi bangunan yang menciptakan kenyamanan termal tersendiri bagi penghuninya sehingga diharapkanmampu mengurangi penggunaan teknologi-teknologi yang dapat menyebabkan kenaikan temperatur secara makro.

\section{KESIMPULAN/RINGKASAN}

Kawasan perkotaan dengan segala bentuk aktivitas warganya, mempengaruhi perubahan iklim yang terjadi secara makro. Hal ini ditandai dengan kenaikan temperatur dan bermunculannya titik pulau panas perkotaan. Tidak terkecuali dengan kawasan Pasar Minggu di wilayah Jakarta Selatan. Dengan rata-rata temperatur mencapai lebih dari $33^{\circ} \mathrm{C}$, kondisi ini tentu bukan termasuk kondisi yang nyaman untuk ditinggali. Hal tersebut dapat mendorong peningkatan pemakaian teknologi seperti AC dan pendingin lainnya. Penggunaan teknologi tersebut justru memberikan efek samping dengan berkontribusi langsung terhadap kenaikan temperatur, Oleh karena itu diperlukan langkah-langkah guna mencapai titik kenyamanan tertentu tanpa harus bergantung dengan teknologi pendingin temperatur.Apartemen Kebagusan City menjawab permasalahan tersebut dengan beberapa rekayasa bangunan. Konfigurasi gedung, bahan dan warna, serta berbagai rekayasa lainnya diciptakan guna menghadirkan kawasan permukiman yang memiliki tingkat kenyamanan optimal bagi penghuninya.

\section{UCAPAN TERIMA KASIH}

Tuturan terima kasih peneliti tujukan kepada mitra pembimbing di program studi Kajian Pengembangan Perkotaan Universitas Indonesia, terutama para pengajar kelas Kepulauan Tropis yang telah memberikan bimbingan untuk melakukan penelitian tentang kenyamanan termal perkotaan.

\section{DAFTAR PUSTAKA}

[1] P. A. Permatasari, L. F. Amalo and A. K. Wijayanto, "Comparison of Urban Heat Island effect in Jakarta and Surabaya, Indonesia," in Sixth International Symposiun on LAPAN-IPN Satelite, Bogor, 2019.

[2] I. Prasasti, Suwarsono and N. M. Sari, "The Effect of Environmental Condition Changes on Distribution of Urban Heat Island in Jakarta Based on Remote Sensing Data," International Journal of Remote Sensing and earth Sciences, vol. 12, no. 1, pp. 27-40, 2015.

[3] I. Prasasti, Parwati, N. M. Sari and B. Febrianti, "Analisis Perubahan Sebaran Pulau Panas Perkotaan (Urban Jeat Island) di Wilayah DKI Jakarta dan Hubungannya dengan Perubahan Lahan, Kondisi Vegetasi dan Perkembangan Kawasan Terbangun Menggunakan Data Penginderaan Jauh," in Pertemuan Ilmiah Tahunan XX, 2015.

[4] S. Latif, R. Rahim and B. Hamzah, "Analisis Kenyamanan Termal Siswa di Dalam Ruang Kelas (Studi Kasus SD Inpres Tamalanrea IV Makassar)," in Simposiun Nasional RAPI XV, Makassar, 2016.

[5] B. Suyono and E. Prianto, "Kajian Sensasi Kenyamanan Termal dan Konsumsi Energi di Taman Srigunting Kota Lama Semarang," Jurnal MODUL Universitas Diponegoro Semarang, vol. 17, no. 2, pp. 17-25, 2017.

[6] W. H. Prasetyo, "Analisa Kinerja Termal dan Aerodinamis Pada Rumah Tradisional Batak Toba Menggunakan Simulasi Digital dan Pengukuran Lapangan," Widyariset, vol. 2, no. 2, pp. 131-142, 2016.

[7] N. W. Mustika and I. W. Sastrawan, "Persepsi Tingkat Kenyamanan Termal Ruang Luar Pada Ruang Publik (Studi Kasus: Taman Kota I Gusti Ngurah Made Agung)," Jurnal Asitektur Warmadewa, vol. 5, no. 1, pp. 45-56, 2017.

[8] Bappenas, Rencana Aksi Nasional Adaptasi Perubahan Iklim (RANAPI), Jakarta: Bappenas, 2014.

[9] T. Hadinata, "Kinerja Kenyamanan Termal Lingkungan Kampung Lerengan Semarang," Universitas Katolik Soegijapranata, Semarang, 2019.

[10] S. Falasca, V. Ciancio, F. Salata, I. Golasi, F. Rosso and G. Curci, "High Albeldo Material to Counteract Heat Waves in Cities: An Assesment of Meteorology, Buildings Energy Needs and Pedestrian Thermal Comfort," in Building and Environment, 2019.

[11] A. Mohammadi, "Wind Performance Based Design for High-Rise Buildings," Florida International University, Miami, 2016.

[12] M. A. Bezabeh, S. Tesfamariam and G. T. Bitsuamlak, "Performancebased wind design of tall buildings: Concepts, frameworks, and opportunities," Wind and Structures, vol. 31, no. 2, pp. 103-142, 2020.

[13] S. N. Qodriyatun, "Upaya Mitigasi dan Adaptasi Perubahan Iklim," Info Kesejahteraan Sosial, vol. 7, no. 1, 2016. 